\title{
Correction to: Occurrence of anti-Leptospira spp. antibodies in Rhipidomys spp. from a forest fragment of the Brazilian Cerrado
}

\author{
D. O. Gomes ${ }^{1}$ - G. B. Ramos ${ }^{1}$ - V. B. A. Alves ${ }^{1}$ - A. Z. Ciuffa ${ }^{1}$ - L. P. Cuccato ${ }^{1}$ - T. F. M. dos Reis ${ }^{1}$ - A. M. C. Lima ${ }^{1}$. \\ M. G. Coelho ${ }^{2}$ - G. V. Tolesano-Pascoli ${ }^{2}$ - V. S. Rodrigues ${ }^{2}$ - M. P. J. Szabó ${ }^{2}$ • V. N. Ramos ${ }^{3}$
}

Published online: 7 January 2019

(C) Springer Nature B.V. 2019

\section{Correction to: Trop Anim Health Prod (2017) 49:555-559 https://doi.org/10.1007/s11250-017-1227-6}

The original version of this article unfortunately contains an error. Vanessa do Nascimento Ramos was inadvertently not included in the original article among the authors. Her name is now included in the group of authors.

Additionally, the names of two authors are not given correctly on the article: "M. C. Gonçalves" must read: Marcella Gonçalves Coelho, which is now given as "M. G. Coelho"; and "G. V. Tolesano" must read: Graziela V. Tolesano-Pascoli, now given as G. V. Tolesano-Pascoli.

Publisher's note Springer Nature remains neutral with regard to jurisdictional claims in published maps and institutional affiliations.

The online version of the original article can be found at https://doi.org/ $10.1007 / \mathrm{s} 11250-017-1227-6$

D. O. Gomes

dayanevet@yahoo.com.br

1 Laboratório de Doenças Infectocontagiosas, Faculdade de Medicina Veterinária of the Universidade Federal de Uberlândia, Rua Ceará, Bloco 2D, Segundo andar, Sala 33, Uberlândia, State of Minas Gerais 38.405-315, Brazil

2 Laboratório de Ixodologia, Faculdade de Medicina Veterinária of the Universidade Federal de Uberlândia, Rua Ceará, Bloco 2D, Segundo andar, Sala 33, Uberlândia, State of Minas Gerais 38.405-315, Brazil

3 Laboratório de Doenças Parasitárias, Departamento de Medicina Veterinária Preventiva e Saúde Animal, Faculdade de Medicina Veterinária e Zootecnia, Universidade de São Paulo, Av. Prof. Orlando Marques de Paiva, 87, Cidade Universitária, São Paulo, SP 05508-270, Brazil 